\title{
LITERATUR REVIEW: MENGKAJI EFEKTIVITAS PEMBERIAN MENTIMUN TERHADAP PENURUNAN TEKANAN DARAH
}

\author{
Arum Meiranny ${ }^{1}$, Astri Syahirani ${ }^{2}$ \\ Program Studi Kebidanan Program Sarjana dan Pendidikan Profesi Bidan, Fakultas Kedokteran, \\ Universitas Islam Sultan Agung ${ }^{1,2}$ \\ e-mail: ${ }^{1}$ arummeiranny@unissula.ac.id, ${ }^{2}$ astrisahira@gmail.com
}

\begin{abstract}
Introduction: Hypertension is a degenerative disease. Those aged $\geq 55$ years are at risk for suffering from hypertension, previously blood pressure prehypertension before being diagnosed with hypertension occurred between the third and fifth decades. The World Health Organization reports as many as 839 million cases of hypertension, by 2025 this figure is expected to increase to 1.15 billion or around 29\% of the world's total population, where female sufferers are more than $30 \%$ compared to male hypertension sufferers, namely $29 \%$. One of the non-pharmacological treatments to treat hypertension is consuming cucumber. Methods: International and national literature searched through electronic media with keyword hints. Eight articles were selected, each of which represents an effectiveness of giving cucumber to reduce blood pressure and provides various information. Results: There was an effect of giving cucumber on reducing blood pressure in respondents. Discussion: One alternative that can be used to lower blood pressure is by consuming cucumber. The diuretic effect on cucumber causes the salt content in the blood to decrease. Reduced levels of salt that absorbs or retains water will reduce blood volume so that it can lighten the work of the heart in pumping blood, and eventually blood pressure will decrease. Conclusion: The conclusion based on the analysis that has been done is that cucumber is effective for lowering blood pressure.
\end{abstract}

Keywords: hypertension; cucumber; blood pressure

\begin{abstract}
ABSTRAK
Pendahuluan: Hipertensi adalah salah satu penyakit degeneratif. Pada umur $\geq 55$ tahun beresiko untuk menderita hipertensi, yang sebelumnya tekanan darahnya prehipertensi sebelum didiagnosis menjadi hipertensi terjadi pada usia diantara dekade ketiga dan dekade kelima. Organisasi Kesehatan Dunia melaporkan sebanyak 839 juta kasus hipertensi, apada tahun 2025 ngka ini diperkirakan akan meningkat menjadi 1,15 milyar atau sekitar $29 \%$ dari total penduduk dunia, dimana penderita wanita lebih banyak yaitu 30\% dibandingkan dengan penderita hipertensi pria yaitu $29 \%$. Salah satu pengobatan nonfarmakologis untuk mengatasi hipertensi adalah dengan mengkonsumsi mentimun. Metode: Literature internasional dan nasional yang ditelusuri melalui media elektronik dengan petunjuk kata kunci. Artikel yang terpilih sebanyak 8 , yang masing-masing mewakili satu efektivitas pemberian mentimun terhadap penurunan tekanan darah dan memberi informasi yang beragam. Hasil: Terdapat pengaruh pemberian mentimun terhadap penurunan tekanan darah pada responden. Pembahasan: Salah satu alternative yang dapat digunakan untuk menurunkan tekanan darah adalah dengan mengkonsumsi mentimun. Efek diuretik pada mentimun menyebabkan kandungan garam dalam darah menurun. Berkurangnya kadar garam yang menyerap atau menahan air akan menurunkan volume darah sehingga dapat meringankan kerja jantung dalam memompa darah, dan akhirnya tekanan darah akan menurun. Kesimpulan: Simpulan berdasarkan analisa yang telah dilakukan adalah penggunakan mentimun efektif untuk menurunkan tekanan darah.
\end{abstract}

Kata kunci: Hipertensi; mentimun; tekanan darah

\section{PENDAHULUAN}

Hipertensi adalah salah satu penyakit degeneratif. Pada umumnya seiring bertambahnya umur secara perlahan tekanan darah juga ikut bertambah. Pada umur $\geq 55$ tahun beresiko untuk menderita hipertensi, yang sebelumnya tekanan darahnya prehipertensi sebelum didiagnosis menjadi hipertensi terjadi pada usia diantara dekade ketiga dan dekade 
kelima. Saat mencapai umur 55 tahun, hipertensi lebih banyak diderita oleh laki-laki dibandingkan dengan perempuan (1). Hipertensi dapat menimbulkan akibat jangka panjang sehingga perlu diperhatikan karena merupakan masalah kesehatan yang angka prevalensinya cukup tinggi (2).

Menurut Basha, Hipertensi merupakan suatu keadaan dimana tekanan darah seseorang diatas normal, keadaan ini dapat mengakibatkan mordibitas dan mortalitas (3). Seseorang didiagnosis hipertensi bila tekanan darah sistolik $\geq 140 \mathrm{mmHg}$ dan atau tekanan darah diastoliknya $\geq 90 \mathrm{mmHg}$, atau bila pasien mengonsumsi obat antihipertensi ${ }^{(4)}$.

Organisasi Kesehatan Dunia (WHO, 2016) melaporkan sebanyak 839 juta kasus hipertensi, pada tahun 2025 angka ini diperkirakan akan meningkat menjadi 1,15 milyar atau sekitar 29\% dari total penduduk dunia, dimana penderita wanita lebih banyak yaitu 30\% dibandingkan dengan penderita hipertensi pria yaitu $29 \%$. Kenaikan kasus hipertensi sekitar $80 \%$ terutama terjadi pada negara-negara berkembang ${ }^{(1)}$.

Berdasarkan penelitian yang dilakukan di Indonesia, sebanyak $25,8 \%$ populasi masyarakat yang berusia di atas 18 tahun merupakan penderita hipertensi, dan dari klasifikasi provinsi diketahui penduduk Jawa Tengah yang mengalami hipertensi sebanyak 26,4\% ${ }^{(5)}$. Dalam kurun waktu 5 tahun terakhir, angka kejadian hipertensi di Semarang mencapai lebih dari $40 \%$ (6).

Penggunaan obat-obatan antihipertensi sering mengakibatkan efek samping yang tidak diinginkan. Efek samping yang umumnya terjadi bila mengkonsumsi obat hipertensi adalah meningkatnya kadar gula dan kolesterol, kelelahan serta kehilangan energi. Untuk menghilangkan efek samping tersebut tidak sedikit penderita harus mengkonsumsi obat lain. cara yang dapat dilakukan untuk menghindari efek samping tersebut adalah dengan

menghentikan terapi pengobatan farmakologis ${ }^{(7)}$

Salah satu pengobatan nonfarmakologis untuk mengatasi hipertensi adalah dengan mengkonsumsi mentimun. Mentimun (Cucumis sativus Linn) dapat menjadi pilihan sebagai obat tradisional. Ketimun dapat menurunkan tekanan darah tanpa efek samping. Mentimun memiliki kandungan mineral, di antaranya kalium, magnesium, dan fosfor. Kalium meningkatkan ekskresi $\mathrm{Na}$, menurunkan renin sekresi, arteriolar vasodilatasi, dan menurunkan respons terhadap endogen vasokonstriktor; sementara magnesium adalah vasodilatasi yang kuat karena menurunkan kontraktilitas otot polos pembuluh darah ${ }^{(8)}$. Selain itu, mentimun juga bersifat diuretik karena mengandung banyak air yang dapat membantu menurunkan tekanan darah ${ }^{(9)}$

\section{METODE}

Dalam mencari artikel pencarian dilakukan dengan data base Google Scholar. Tujuan dari artikel ini adalah untuk membahas masalah hipertensi. Kata kunci yang digunakan untuk pencarian literature yaitu "the effect of cucumber on hypertension". Cara yang digunakan dalam mencari artikel menggunakan bahasa Inggris dan bahasa Indonesia yang relevan dengan topik. Kata kunci yang digunakan adalah "Cucumber/Mentimun", "Hypertension/- hipertensi", "Tekanan Darah". Artikel yang diperoleh di review untuk memilih artikel yang sesuai dengan kriteria dan di dapatkan 8 artikel yang terdiri dari 5 artikel internasional dan 3 artikel nasional yang selanjutnya akan di review.

Artikel penelitian yang diteliti yang berjudul "Effect Of Cucumber (Cucumis Sativus) Juice On Lowering Blood Pressure In Elderly". Penelitian ini menggunakan metode preeksperimen dengan one group pretest-posttest, pengambilan sampel menggunakan random sampling. responden diberikan jus mentimun yang diblender dengan komposisi mentimun 100 gram dan air 200cc. Jus tersebut dikunsumsi selama 7 hari sebanyak dua kali sehari. Tekanan darah di ukur menggunakan Sphygmoanometer. Tekanan darah normal bila sistolik berkisar antara 120-140 $\mathrm{mmHg}$ dan diastolik berkisar antara $80-90 \mathrm{mmHg}$. Sedangkan hipertensi terjadi jika tekanan darah lebih dari 140/90 mmHg. Uji statistik menggunakan T-test. Hasil penelitian menunjukkan bahwa $t$ hitung $>t$ tabel $(6,190>2,093)$ atau (nilai $\mathrm{P} 0,000>\alpha 0,05)$. Sehingga dapat disimpulkan bahwa Ho ditolak yang artinya ada pengaruh yang signifikan jus ketimun (Cucumis sativus) terhadap penurunan tekanan darah pada lansia ${ }^{(9)}$

Artikel penelitian yang berjudul "The Effectiveness of Cucumber Suri Juice (Cucumis Sativus) On Blood Pressure in Menopausal Hypertension". Penelitian ini menggunakan metode Quasi Experimental pre-test dan post test with control group design. Pengambilan sampel 


\section{Vol. 16 No.2 Mei - Agustus 2021}

menggunakan teknik lotre. Jumlah sampel 20 responden (10 kontrol dan 10 intervensi). Kelompok perlakuan diberikan 400 gram sari mentimun suri dan kaptopril sedangkan kelompok kontrol mendapatkan obat kaptopril yang diberikan selama 7 hari. Uji statistik menggunakan uji homogenitas, uji independent T-test dan paired T-test. Hasil penelitian ini menunjukkan bahwa ada perbedaan yang bermakna pada tekanan darah diastolik sebelum dan sesudah perlakuan ( $p$ value $<0,05$ ), pada kelompok kontrol tidak terdapat perbedaan bermakna ( $p$ value $>0,05$ ) sehinggan pemberian pemberian jus ketimun dan obat antihipertensi menurunkan tekanan darah sebesar $16,60 \mathrm{mmHg}$, sedangkan pemberian obat antihipertensi saja hanya mampu menurunkan tekana darah diatolik sebesar $1,30 \mathrm{mmHg}{ }^{(10)}$

Artikel penelitian yang berjudul "The Effect Of Cucumber Juice (Cucumis Sativus) Toward Hypertension Of Elderly At Tresna Werdha budi Sejahtera Social Institutin Of Banharbaru South Borneo 2017". Penelitian ini menggunakan metode quasi experiment with one group pre-post test design. Pengambilan sampel menggunakan non-probability sampling dengan purposive sampling. Jumlah sampel 35 responden. Responden diberikan 200 gram ketimun dan $100 \mathrm{ml}$ air yang diberikan setiap jam 09.00 WITA selama 3 hari. Hasil penelitian ini menunjukkan bahwa $\mathrm{p}=0,000<\alpha 0,05$, sehingga dapat disimpulkan bahwa terdapat pengaruh pemberian jus ketimun terhadap penurunan tekanan darah sistolik dan diastolik pada lansia hipertensi ${ }^{(11)}$

Artikel penelitian yang berjudul "Cucumber (Cucumis sativus) and Tomato (Solanum lycopersicum) Juice Effective to reduce Blood Pressure". Penelitian ini menggunakan metode quasi-experimental study with pretest-posttest without control. Pengambilan sampel menggunakan quota sampling. Jumlah sampel 18 responden yang berikan jus ketimun dan 18 responden yang diberikan jus tomat. Kelompok perlakuan yang diberikan jus mentimun dengan komposisi jus mentimun dibuat dari 200 gram mentimun yang sudah dibersihkan kemudian dihaluskan menggunakan juicer didapat $180 \mathrm{ml}$ jus mentimun, diberikan setiap pagi selama 7 hari. Uji statistik menggunakan uji normalitas dengan Shapiro Wilk test. Hasil penelitian ini menunjukkan pada kelompok pemberian jus ketimun rata-rata tekanan darah sistolik pretestpostest mengalami penurunan sebesar 4,11 mmHg menunjukkan $\mathrm{p}$ value 0,000 yang berarti bahwa jus ketimu efektif menurunkann tekanan darah sistolik dan diastolik ${ }^{(12)}$

Artikel penelitian yang berjudul "Effect Of Juice And Brisk Walking On Blood Pressure In Elderly Hypertension Patients". Penelitian ini menggunakan metode quasi experimental with pre-test and post-test design. Pengambilan sampel menggunakan purposive sampling. Jumlah sampel 40 responden, dengan 20 responden yang diberikan jus ketimun dan 20 responden yang diberikan perlakuan brisk walking. Kelompok yang diberikan jus mentimun yang diberikan selama 7 hari dengan dosis $150 \mathrm{ml}$ (200 gram/150 ml). Uji statistik yang digunakan Shapiro Wilk test. Hasil penelitian menunjukkan paird t test menunjukkan bahwa pemberian jus ketimun memiliki perbedaan rata-rata tekanan darah sistolik $\mathrm{p}=0,000(<0,05)$ dan diastolik $\mathrm{p}=$ $0,000(<0,05)$ sebelum dan sesudah intervensi ketimun, sehingga dapat disimpulkan bahwa ada pengaruh yanb signifikan konsumsi jus ketimun terhadap penurunan tekanan darah ${ }^{(13)}$

Artikel penelitian yang berjudul "Terapi Jus Mentimun Menurunkan tekanan Darah Pada Penderita Hipertensi". Penelitian ini menggunakan metode Quasi Experiment dengan one group Pre-Post Test Design. Jumlah sampel yang digunakan sebanyak 23 responden. Tekanan darah diukur menggunkan alat sphygmomanimeter dan stetoskop. Uji statistik yang digunakan menggunakan Wilcoxon Sign Rank Test. Hasil penelitian menunjukkan hasil p $<$ a $(0,001<0,05)$, yang berarti bahwa ada perbedaan yang signifikan antara rerata nilai tekanan darah sebelum dan sesudah intervensi ${ }^{(14)}$

Artikel penelitian yang berjudul "Pengaruh Pemberian Jus Mentimun Terhadap Tekanan Darah Pada Penderita Hipertensi Di Desa Tolobukan Kec. Pasan Kab. Minahasa Tenggara Tahun 2015". Penelitian ini menggunakan metode Quasi-experimental design dengan Pretest-posttest with control group. Pengambilan sampel dengan Non Probability Sampling dengan cara Purposive Sampling. Jumlah sampel yang digunakan 32 responden (16 0rang kelompok pemberian jus mentimun dan 16 orang kelompok tanpa pemberian jus mentimun). Uji statistik yang digunakan yaitu uji beda dua mean (Uji t). Hasil penelitian menunjukkan p Value adalah 0,000 dengan $\alpha<0,05$, yang berarti $p$ 
Value $<\alpha(0,000<0,05)$ terlihat adanya perbedaan yang signifikan yaitu rata-rata tekanan darah pada penderita hipertensi pada kelompok intervensi yang diberi jus mentimun dengan tekanan darah pada penderita hipertensi pada kelompok kontrol tanpa diberi jus mentimun ${ }^{(15)}$

Artikel penelitian yang berjudul "Efektivitas Konsumsi Jus Mentimun Terhadap Penurunan Tekanan Darah Pada Pasien Hipertensi", penelitian ini menggunakan metode Quasy Experiment dengan rancangan penelitian NonEquivalent Control Group. Pengambilan sampel menggunakan teknik purposive sampling. Sampel yang terpilih sebanyak 30 responden (15 kelompok eksperimen dan 15 kelompok kontrol). Pada kelompok perlakuan diberikan jus mentimun setiap hari selama 7 hari sebanyak 1 gelas $( \pm 200 \mathrm{cc})$ yang diberikan setiap sore hari. Uji statistik yang digunakan adalah uji beda dua meanindependent sample t-test. Cara mengukur tekanan darah menggunakan alat sphygmomanometer digital. Hasil penelitian menunjukkan Dari hasil uji statistik didapatkan adanya penurunan yang signifikan antara mean tekanan arteri rata-rata (MAP) sebelum dan sesudah diberikan jus mentimun pada kelompok eksperimen dimana $\mathrm{p}$ value $=0,000$ dengan $5 \%$ $(\mathrm{p}<0,05)^{(7)}$

\section{HASIL DAN PEMBAHASAN}

Dari hasil literature review yang telah dipaparkan. Terdapat pengaruh mentimun terhadap penurunan tekanan darah pada responden. Mentimun memiliki efek hipotensi dalam menurunkan tekanan darah dan efek diuretik yang menurunkan jumlah cairan yang bersirkulasi dalam aliran darah, yang pada akhirnya dapat mengurangi beban kerja jantung ${ }^{(16)}$ hal ini dapat dikatakan bahwa dengan cara kerja terapi pemberian jus mentimun sama dengan obat diuretik anti hipertensi dalam menurunkan tekanan darah.

Efek diuretik pada mentimun menyebabkan kandungan garam dalam darah menurun. Berkurangnya kadar garam yang menyerap atau menahan air akan menurunkan volume darah sehingga dapat meringankan kerja jantung dalam memompa darah, dan akhirnya tekanan darah akan menurun. Kalium merupakan mineral yang berfungsi mengatur keseimbangan cairan tubuh. Konsumsi kalium dalam jumlah banyak akan meningkatkan konsentrasinya pada cairan intraseluler, sehingga menarik cairan dari bagian ekstraseluler dan menurunkan tekanan darah ${ }^{(17)}$

Pengaruh pemberian mentimun terhadap tekanan darah terlihat jelas pada peran kalium, kalsium, dan magnesium untuk memompa kalium - natrium. Kekurangan kalium dalam darah akan mengganggu rasio kalium-natrium sehingga kadar natrium akan meningkat. Hal tersebut dapat menyebabkan pengendapan kalsium pada persendian dan tulang belakang yang meningkatkan kadar air dalam tubuh, sehingga meningkatkan beban kerja jantung dan penggumpalan natrium pada pembuluh darah. Akibatnya, dinding pembuluh darah bisa terkikis dan terkelupas yang akhirnya menyumbat aliran darah, dan meningkatkan risiko hipertensi dengan jus mentimun sehingga kemungkinan besar akan diatasi ${ }^{(18)}$

Penurunan tekanan darah terjadi karena ketimun memiliki kandungan kalium yang dapat menurunkan sekresi renin yang berujung pada penghambatan Sistem Renin-Angiotensin juga menyebabkan penurunan sekresi aldosteron, sehingga mengakibatkan penurunan reabsorpsi natrium dan air di tubulus ginjal. Akibat mekanisme ini, terjadi peningkatan diuresis yang menyebabkan penurunan volume darah, sehingga tekanan darah pun turun. Selain itu, kalium juga menyebabkan vasodilatasi pembuluh darah tepi, sehingga terjadi penurunan tahanan tepi, dan tekanan darah juga turun ${ }^{(11)}$

Dalam mengontrol tekanan darah dapat diberikan mentimun yang dapat menurunkan tekanan darah secara teratur, kandungan mentimun yang dikonsumsi dapat mengurangi risiko terkena hipertensi dengan membantu mengurangi ketegangan otot dan emosional responden. Hasil-hasil penelitian ini menunjukkan bahwa mengkonsumsi jus mentimun berpengaruh atau memiliki efek yang positif terhadap tekanan darah ${ }^{(14)}$

\section{KESIMPULAN DAN SARAN}

\section{Kesimpulan}

Berdasarkan analisa yang telah dilakukan oleh penulis, dapat disimpulkan bahwa pemberian mentimun efektif untuk menurunkan tekanan darah pada penderita hipertensi.

Saran

Saran yang dapat diberikan untuk pelaksanaan literature review selanjutnya adalah sebaiknya bisa menggunakan database yang lebih 


\section{Vol. 16 No.2 Mei - Agustus 2021}

banyak sehingga bisa mendapatkan artikel yang lebih banyak dan baik serta batasan tahun artikel dengan kata kunci yang ditetapkan yaitu lima tahun terakhir sehingga literature yang digunakan bisa lebih update.

Saran bagi penderita hipertensi bisa menggunakan Jus mentimun sebagai pengobatan alternatif untuk menurunkan tekanan darah.

\section{DAFTAR PUSTAKA}

1. Triyanto endang. pelayanan keperawatan bagi penderita hipertensi. yogyakarta: graha ilmu; 2014.

2. Tjokronegoro A, Utama H. Buku Ajar Penyakit Dalam. Jakarta: Balai Penerbit FKUI; 2001. 453 p.

3. Basha A. Hipertensi: Faktor Resiko Dan Penatalaksanaan. Jakarta: Dian Rakyat; 2004.

4. Mansjoer A dkk. Kapita Selekta Kedokteran Jilid 1. Jakarta: Media Aesculapius; 2001.

5. Riskesdas. Buku Penelitian dan Pengembangan Kesehatan kementarian Kesehatan RI. Laporan Hasil Riset Kesehatan Dasar (RISKESDAS) Nasional 2013. Jakarta; 2013. 123 p.

6. Dinkes. Profil Kesehatan Kota Semarang 2012. Semarang: Dinas Kesehatan Kota Semarang; 2012. $70 \mathrm{p}$.

7. Kharisna D, Dewi WN, Lestari W. Efektifitas konsumsi jus mentimun terhadap penurunan tekanan darah pada pasien hipertensi. J Ners Indones. 2012;2(2):124-31.

8. Soeryoko H. Tanaman Obat terpopuler Penurun Hipertensi. yogyakarta: Andi; 2010.

9. Pertami SB, Rahayu DYS, Budiono B. Effect of Cucumber (Cucumis Sativus) Juice on Lowering Blood Pressure in Elderly. Public Heal Indones. 2017;3(1):30-6.

10. Hariyanti R, Hadisaputro S, Sumarni S, Widyastuti E. The Effectiveness of Cucumber Suri Juice (Cucumis Sativus) On Blood Pressure In Menopausal Hypertension. Str J Ilm Kesehat. 2020;9(2):1771-8.

11. Negara candra kusuma, Erna. THE EFFECT OF CUCUMBER JUICE ( $\mathrm{C}$ u c $\mathrm{u} \mathrm{m}$ i $\mathrm{s} \mathrm{S}$ a $\mathrm{t} \mathrm{i} \mathrm{v} u \mathrm{~s}$ ) TOWARD HYPERTENSION OF ELDERLY AT TRESNA WERDHA BUDI SEJAHTERA SOCIAL INSTITUTION OF BANJARBARU SOUTH BORNEO 2017. Indones J Nurs Pract. 2018;2(1).

12. Siti Fadlilah, Adi Sucipto, Mohamad Judha. Cucumber (Cucumis sativus) and tomato (Solanum lycopersicum) juice effective to reduce blood pressure. GSC Biol Pharm Sci. 2020;10(1):001-7.

13. Chalida N, Ziadatul E, Melati F, Dwi M, Sugiarto A. Effect Of Cucumber Juice And Brisk Walking Exercise On Blood Pressure In Elderly Hypertension Patients. Midwifery Nurs Res. 2019;1(1):51.

14. Barus M, Ginting A, Turnip AJ. Terapi Jus Mentimun Menurunkan Tekanan Darah Pada Penderita Hipertensi. J Mutiara Ners. 2019;2(2):230-7.

15. Ponggohong CE, Rompas SS., Ismayanto YA. PENGARUH PEMBERIAN JUS MENTIMUN TERHADAPTEKANAN DARAH PADA PENDERITA HIPERTENSIDI DESA TOLOMBUKAN KEC. PASAN KAB. MINAHASA TENGGARA TAHUN 2015. ejournal Keperawatan (e-Kp. 2015;3(2).

16. Khomsan. Pangan dan Gizi untuk Kesehatan, PT. Grafindo Persada, Jakarta. Jakarta: grafindo persada; 2004.

17. Franklin M, Haroen ER, Tjahajawati S. Differences in blood pressure before and after consuming cucumber juice (Cucumis sativus) in women aged 30-40 years. Padjadjaran J Dent. 2010;22(3):167-70.

18. Julianti elisa diana, Nunung $\mathrm{N}$, soetrisno uken. bebas hipertensi dengan terapi jus. Jakarta: puspa swara; 2005. 